\title{
KOMUNIKASI PENDIDIK TERHADAP ANAK BERKEBUTUHAN KHUSUS DI SEKOLAH KHUSUS ASY-SYIFA LARANGAN
}

\author{
SAIHU \\ Institut PTIQ Jakarta \\ madesaihu@ptiq.ac.id
}

\begin{abstract}
ABSTRAK
Tulisan ini membahas tentang model komunikasi pendidik terhadap peserta didik berkebutuhan khusus di Sekolah Khusus Asy-syifa Larangan Tangerang. Tulisan ini berfokus pada penelusuran model interaksi yang digunakan oleh pendidik dalam memberikan materi pelajaran kepada anak berkebutuhan khusus. Sumber data diperoleh melalui observasi dan wawancara tak terstruktur selama bulan Agustus sampai dengan Maret Nopember 2019. Tulisan menggunakan teori interaksionisme simbolik yang dikemukakan oleh Herbert Blumer. Tulisan memperlihatkan bahwa proses pembelajaran di dalam kelas terhadap anak berkebutuhan khusus dilakukan secara individu dengan melibatkan 3 orang guru dalam satu kelas. Sementara metode yang digunakan adalah metode demonstrasi dimana guru bertugas sebagai model dalam pembelajaran tersebut. Melalui metode ini, proses meaning (pemaknaan), language (kebahasaan), dan thought (pemikiran) dapat ditransferkan ke peserta didik dengan baik.
\end{abstract}

Kata Kunci : Komunikasi, Interaksi Simbolik, Demonstrasi, Karakter.

\begin{abstract}
This paper discusses the communication model of educators towards students with special needs in the Asy-syifa Larangan Tangerang Special School. This paper focuses on tracing the interaction model used by educators in providing subject matter to children with special needs. Data sources were obtained through unstructured observations and interviews from August to March November 2019. The writing used the symbolic interactionism theory put forward by Herbert Blumer. Writing shows that the learning process in the classroom with children with special needs is done individually by involving 3 teachers in one class. While the method used is a demonstration method where the teacher is assigned as a model in the learning. Through this method, the process of meaning, language and thoughts can be transferred to students well.
\end{abstract}

Keywords: Communication, Symbolic Interaction, Demonstration, Character. 


\section{A. PENDAHULUAN}

Satu ungkapan populer tentang komunikasi adalah "manusia tidak dapat tidak berkomunikasi". Selama manusia hidup, ia pasti berkomunikasi. Manusia berkomunikasi dengan dirinya sendiri dan orang lain. Manusia juga berkomunikasi dengan menggunakan media atau saluran komunikasi. Perangkat modern, seperti telepon selular, komputer dan komputer tablet merupakan perangkat yang kita pergunakan untuk berkomunikasi, baik secara lisan maupun tertulis.

Karena manusia tidak dapat tidak berkomunikasi, maka ketiadaan komunikasi atau tidak bisa berkomunikasi dengan orang lain bisa merupakan bentuk ketidaknyamanan atau siksaan bagi manusia. Sebagai contoh bagaimana tersiksanya manusia karena tidak bisa berkomunikasi, dapat kita lihat dari anakanak yang menghukum teman mainnya dengan cara tidak ditegur, tidak diajak berbicara, atau didiamkan oleh teman-teman mainnya. Didiamkan teman merupakan hukuman yang menyiksa anak tersebut karena ia merasa dikucilkan. Kita juga dapat menyaksikan bagaimana orang yang merasa " menderita" hanya karena baterai telepon selularnya habis atau pulsanya habis. Bukan habis baterai atau pulsa yang membuatnya merasa menderita, melainkan tidak bisa berkomunikasinya. ${ }^{1}$

Komunikasi merupakan komponen terpenting bagi setiap organism untuk melangsungkan kehidupan mereka. Urgensi komunikas bersifat menyeluruh melingkupi kebutuhan semua individu yang dapat teridentifikasi dari beragam cara mereka dala melakukan interaksi. Dalam dinamika kehidupan manusia manapun organism yang lain, eksistensi komunikasi menjadi prasyarat mutlak untuk dapat melakukan adaptasi. Ketika kemampuan komunikasi tidak dapat dimiliki individu maka akan menghambat dirinya untuk survive terlebih untuk melakukan aktualisasi diri. ${ }^{2}$

Manusia berkomunikasi karena, pertama, manusia tidak bisa hidup sendiri. Manusia membutuhkan kehadiran orang lain. kontak dengan orang lain itu dilakukan dengan berkomunikasi. Orang bisa berjam-jam berbincang-bincang dengan teman nya dengan topik pembicaraan yang berganti-ganti, seperti menyampaikan fakta atau menyampaikan pikiran dan imajinasinya. Kontak dengan orang lain melalui komunikasi itulah yang membuat manusia bisa menjaga relasinya dengan orang lain. Jadi, iteraksi sosial dengan sesama manusia itulah yang membuat manusia butuh untuk berkomunikasi. Disini berkomunikasi dilakukan untuk menjaga relasi.

Kedua, manusia berkomunikasi dengan orang lain untuk menyampaikan pikiran, gagasan atau perasaannya. Informasi atau pesan (message) dipertukarkan diantara sesamanya. Informasi tersebut bisa berupa informasi faktual, seperti

1 Yosal Iriantara dan Usep Syarifudin, Komunikasi Pendidikan (Bandung: Simbiosa Rekatama Media, 2018), 3.

2 Fatma Laili Khoirun Nida, "Komunikasi Bagi Anak berkebutuhan Khusus", Jurnal Komunikasi Penyiaran Islam, Dosen Jurusan Dakwah dan Komunikasi STAIN Kudus, 2013: 164. 
terjadinya satu peristiwa baik dilingkungan sendiri maupun di dunia. Bisa juga berupa konsep, seperti yang diajarkan para pendidik pada anak didiknya saat mengajarkan rumus matematika atau teori fisika.

Dengan demikian, komunikasi antarmanusia selalu memiliki dua dimensi yaitu relasi dan informasi. Ada saatnya, kita berkomunikasi untuk bertukar pesan atau informasi. Ada kalanya juga kita berkomunikasi untuk menjaga relasi sehingga kita melakukan apa yang dinamakan basa-basi seperti bertanya "apa kabar?" saat bertemu seorang teman disekolah atau kantor. Kedua dimensi dalam komunikasi ini tidak hanya diwujudkan dalam komunikasi verbal tetapi juga dalam bentuk komunikasi nonverbal yang menggunakan misalnya nada suara dan gerak tubuh.

Lantas, apa sebenarnya komunikasi? Pertanyaan sederhana ini bisa menghasilkan banyak jawaban. Ada yang menjawabnya dengan melihat komunikasi sebagai proses. Ada juga yang menjawabnya dengan melihat komunikasi sebagai hasil tindakan manusia atau karya manusia. Ada juga yang menjawab komunikasi manusia itu merefleksikan bagaimana kekuatan-kekuatan sosial saling memengaruhi dan berusaha mencapai donasinya.

Secara sederhana biasanya komunikasi dijelaskan sebagai proses penyampaian pesan dari penyampaian pesan (communicator) kepada komunikan (penerima pesan) dengan tujuan tertentu. Komunikasi merupakan komponen terpenting bagi setiap organism untuk melangsungkan kehidupan mereka. Urgensi komunikasi bersifat menyeluruh melingkupi kebutuhan semua individu yang dapat teridentifikasi dari beragam cara mereka dalam melakukan interaksi. Dalam dinamika kehidupan manusia maupun organism yang lain, eksistensi komunikasi menjadi prasyarat mutlak untuk dapat melakukan adaptasi. Ketika kemampuan komunikasi tidak dapat dimiliki individu maka akan menghambat dirinya untuk survive terlebih untuk melakukan aktualisasi diri. ${ }^{3}$

Berdasarkan perspektif diatas, dapat menemukan sejumlah faktor dalam komunikasi, yaitu:

1. Komunikasi itu menggunakan kata-kata dan sinyal nonverbal

2. Komunikasi itu memengaruhi tindakan dan ide-ide orang lain

3. Setiap pesa komunikasi memerlukan pengirim, penerima dan media atau saluran yang dipergunakan untuk menyampaikan pesan tersebut

4. Pesan yang disampaikan bisa di salah pahami bila orang berbeda persepsi atau tidak berada pada gelombang yang sama ${ }^{4}$

Komunikasi selalu menjadi bagian tak terpisahkan dari interaksi sosial. Interaksi sosial itu bisa berupa interaksi ekonomi, interaksi politik atau interaksi edukatif. Pada setiap interaksi itu tentu saja akan terjadi komunikasi verbal maupun nonverbal. Tidak bisa kita bayangkan, akankah ada interaksi sosial yang berlangsung tanpa ada komunikasi?

${ }^{3}$ Fatma Laili Khoirun Nida, "Komunikasi bagi anak berkebutuhan khusus", at-tabsyir, journal komunikasi penyiaran islam, Vol. 1, 2013: 164.

${ }^{4}$ Yosal Iriantara dan Usep Syarifudin, Komunikasi Pendidikan, 7. 
Dalam tradisi pendekatan penelitian ilmu komunikasi, terdapat beberapa komunikasi. Salah satunya adalah teori interaksi simbolik yang berakar dari semioka dan fenomenologi, sehingga dapat dikatakan bahwa interaksionisme simbolik merupakan sebuah teori yang paling berpengaruh dalam sejarah bidang studi komunikasi.

Teori interaksi simbolik bermula dari interaksionisme simbolik yang di gagas oleh George Herbert Mead yakni sebuah perspektif sosiologi yang dikembangkan pada kisaran abad 20 dan berlanjut menjadi beberapa pendekatan teoretis yaitu aliran lowa yang di prakarsai oleh Herbert Blumer, aliran low yang diprakarsai oleh Manford Kuhn, dan aliran indiana yang diprakarsai oleh Sheldon Stryker.

Dalam analisanya, tulisan ini menggunakan teori komukasi interaksi simbolis Herbert Blumer. Blumer mendefinisikan interaksionisme simbolik atau teori interaksi sebagai sebuah proses interaksi dalam rangka membentuk arti atau makna bagi setiap individu. Dia menambahkan, bahwa teori interaksi simbolis menitikberatkan pada tiga prinsip utama komunikasi yaitu: pemaknaan (meaning), bahasa (language), dan pikiran (tought).

\section{1). Meaning}

Berdasarkan teori interaksi simbolis, meaning atau makna tidak inheren dalam objek namun berkembang melalui proses interaksi sosial antar manusia karena itu makna berada dalam konteks hubungan baik keluarga maupun masyarakat. Makna dibentuk dan dimodifikasi melalui proses interpretatif yang dilakukan oleh manusia.

2). Language

Sebagai manusia, seseorang memiliki kemampuan untuk menamakan sesuatu. Bahasa merupakan sumber makna yang berkembang secara luas melalui interaksi sosial antara satu dengan yang lainnya dan bahsa disebut juga sebagai alat atau instrument. Terkait dengan bahasa, Mead menyatakan bahwa dalam kehidupan sosial dan komunikasi antar manusia hanya mungkin dapat terjadi jika individu tersebut memahami dan menggunakan sebuah bahasa yang sama.

3). Thought

Thought adalah pemikiran berimplikasi kepada interprestasi yang diberikan seseorang terhadap simbol. Dasar dari pemikiran adalah bahasa yaitu suatu proses mental mengkorvengensi makna, nama, dan simbol. Pemikiran termasuk imaginasi yang memiliki kekuatan untuk menyediakan gagasan walaupun tentang suatu yang tidak diketahui berdasarkan pengetahuan yang diketahui. Misalnya adalah berfikir. ${ }^{5}$

Lalu bagaimana model komunikasi kepada anak berkebutuhan khusus di SDM di Sekolah Khusus Asy-Syifa Larangan Tangerang?

${ }^{5}$ Everett. M. Rogers, A History of Communication Study: A Biographical Approach (New York : The Free Press, 1994), 88. 


\section{B. METODE}

Dalam penelitian ini penulis menggunakan jenis penelitian kualitatif. Yaitu mengeksplorasi bagaimana model komunikasi pendidikan anak berkebutuhan khusus di sekolah Asy-Syifa, Larangan, Tangerang Selatan. Dalam pengumpulan data, penulis mengambil data langsung di lembaga tersebut melalui prosedur dan teknik pengambilan data yang berupa observasi, ${ }^{6}$ wawancara, ${ }^{7}$ dokumentasi, ${ }^{8}$ maupun penggunaan instrument pengukuran lainnya yang khusus dirancang sesuai dengan tujuan peneliti.

Untuk mendapatkan keabsahan data diperlukan teknik pemeriksan. Pelaksanaan teknik pemeriksaan didasarkan atas sejumlah kriteria tertentu. Ada empat kriteria yang digunakan, yaitu derajat kepercayaan, keterlibatan, kebergantungan, dan kepastian. ${ }^{9}$

Kriteria pertama mengenai derajat kepercayaan temuan/nilai kebenaran pada penelitian ini ditempuh oleh peneliti dengan cara meningkatkan ketekunan, memakai triangulasi, menyertakan bahan referensi lain, dan teknik diskusi dengan teman sejawat. Kemudian data yang diperoleh di analisis secara induktif berdasarkan data yang diperoleh, menggunakan model analisis milik Miles dan Huberman, yaitu melalui tiga tahapan, yaitu: 1) Reduksi data (merangkum, memilih hal-hal pokok, memfokuskan pada hal penting untuk dicari tema dan polanya); 2) Paparan data (memetakan, mengorganisir, mengolah, data yang diperoleh); 3) Penarikan kesimpulan data dan verifikasi. ${ }^{10}$

\section{HASIL DAN PEMBAHASAN}

Agar pembahasan lebih sistematis dan terarah, maka peneliti membagi kedalam empat pembahasan, yaitu deskripsi subjek penelitian, deskripsi hasil penelitian, rangkuman hasil penelitian, dan pembahasan. Data diperoleh dari

6 Observasi adalah suatu metode pengumpulan data yang digunakan dengan jalan mengadakan pengamatan yang disertai dengan pencatatan-pencatatan terhadap keadaan atau perilaku objek sasaran yang dilakukan secara langsung pada lokasi yang menjadi objek penelitian Abdurahman Fatoni, Metodologi Penelitian dan Teknik Penyusunan Skripsi (Jakarta: Rineka Cipta, 2006), 104.

7 Wawancara adalah teknik pengumpulan data melalui proses tanya jawa lisan yang berlangsung satu arah, artinya pertanyaan datang dari stu pihak yang mewawancarai dan jawaban diberikan oleh yang diwawancarai Abdurahman Fatoni, Metodologi dan Teknik Penyusunan Skripsi, 105.

${ }_{8}^{8}$ Dokumentasi adalah ditujukan untuk memperoleh data langsung dari tempat penelitian meliputi: buku-buku yang relevan, peraturan-peraturan, laporan kegiatan, foto-foto, film dokumenter data yang relevan penelitian Ridwan, Metode dan Teknik Penyusunan Tesis (Bandung: Alfabeta, 2006), 105. 324.

${ }^{9}$ Lexy J Moeleong, Metodologi Penelitian Kualitatif (Bandung: PT Remaja Rosdakarya, 2013),

${ }^{10}$ Sugiono, Metode Penelitian Kuantitatif, Kualitatif, dan RED, (Bandung: Alfabeta, 2008), h. 96 
beberapa subjek penelitian yaitu pertama Kepala Sekolah, kemudian Wali Kelas IX, Orang tua muris Autism dan Anak didik kelas IX.

Berdasarkan hasil wawancara dengan nara sumber atau informan, peneliti dapat menganalisis tentang sikap dan pola asuh dalam komunikasi pendidikan anak berkebutuhan khusus, meliputi bagaimana sikap guru dan orang tua terhadap anaknya yang menyandang autis atau anak berkebutuhan khusus, sikap yang dimaksud adalah pembentukan atau perubahan sikap positif atau sikap negative orang tua dalam penerimaan anaknya yang menyandang kebutuhan khusus (autis) dan seperti apa pola komunikasi yang diterapkan guru dan orang tua baik di sekolah maupun di rumah terhadap anak-anak berkebutuhan khusus (autis).

Adapun daftar nama dan kode informan dijelaskan dalam rincian pada tabel 4.1. pengkodean tersebut digunakan untuk memudahkan analisis data penelitian Pengkodean informan dalam penelitian ini berdasarkan inisial subjek dan posisi subjek.

Tabel. 1. Daftar nama subjek dan kode subjek

\begin{tabular}{|c|c|c|c|}
\hline No & Nama Subjek & Posisi Subjek & Kode Subjek \\
\hline 1 & $\begin{array}{c}\text { Evi } \\
\text { Sulistiawati }\end{array}$ & Kepala Sekolah & S1 \\
\hline 2 & Dina & Guru kelas IX & S2 \\
\hline 3 & Intan & $\begin{array}{c}\text { Orang tua } \\
\text { Murid }\end{array}$ & S3 \\
\hline 4 & Pasha & Murid & S4 \\
\hline
\end{tabular}

Untuk mendukung pelaksanaan pengambilan data observasi dan wawancara, peneliti menggunakan alat perekam dan video dalam mengelola hasil wawancara suara ke dalam transkrip wawancara, dan untuk merekam kejadian yang bukan berupa suara peneliti menggunakan alat tulis.

Jadwal pelaksanaan pengumpulan data di lapangan beserta Subjek dan lokasi diuraikan dalam tabel 4.2 dibawah ini.

Tabel. 2. Jadwal pelaksanaan pengumpulan data

\begin{tabular}{|c|c|c|c|}
\hline No & Hari/tanggal & $\begin{array}{c}\text { Pengumpulan } \\
\text { data }\end{array}$ & Keterangan \\
\hline 1 & Selasa, 30 juli 2019 & $\begin{array}{c}\text { Observasi dan } \\
\text { dokumentasi }\end{array}$ & $\begin{array}{c}\text { Lapangan dan Kelas } \\
\text { IX }\end{array}$ \\
\hline 2 & Rabu, 31 Juli 2019 & $\begin{array}{c}\text { Observasi dan } \\
\text { dokumentasi }\end{array}$ & $\begin{array}{c}\text { Lapangan dan Kelas } \\
\text { IX }\end{array}$ \\
\hline 3 & Kamis, 1 Agustus & $\begin{array}{c}\text { Observasi dan } \\
\text { Dokumentasi }\end{array}$ & $\begin{array}{c}\text { Lapangan dan Kelas } \\
\text { IX }\end{array}$ \\
\hline 4 & Jum'at, 2 Agustus & Observasi, & Lapangan, Kelas, dan \\
\hline
\end{tabular}




\begin{tabular}{|c|c|c|c|}
\hline & 2019 & $\begin{array}{c}\text { Wawancara } \\
\text { dan } \\
\text { Dokumentasi }\end{array}$ & Ruang Kantor \\
\hline 5 & Senin, 19 Agustus & $\begin{array}{c}\text { Observasi, } \\
\text { Wawancara } \\
\text { dan } \\
\text { Dokumentasi }\end{array}$ & $\begin{array}{c}\text { Lapangan, Kelas, dan } \\
\text { Ruang Tunggu } \\
\text { Orang tua }\end{array}$ \\
\hline 6 & Kamis, 29 Agustus & $\begin{array}{c}\text { Observasi dan } \\
\text { Dokumentasi }\end{array}$ & Lapangan dan Kelas \\
\hline
\end{tabular}

\section{Paparan Data dan Analisis Data}

Setelah melakukan penelitian di Sekolah Khusus Asy-Syifa Larangan Kota Tangerang, peneliti mendapati hasil kegiatan tentang komunikasi pendidikan anak berkebutuhan khusus. Sebelum menguraikan masalah tentang bagaimana proses komunikasi pendidikan anak berkebutuhan khusus dan strategi komunikasi pendidikan pada anak berkebutuhan khusus peneliti sedikit akan memberikan gambaran secara eksplisit terkait karakter siswa, yang di dalam kelas. Dalam kelas IX terdiri dari 6 siswa, dan tidak boleh lebih dari 7 siswa perkelasnya maksimal 6 siswa setiap kelasnya. Kebanyakan terdiri dari tunagrahita ringan, dimana mereka mampu untuk membaca dan menulis. Dan down syndrome, mereka juga mampu membaca akan tetapi hanya perhuruf, dan lamban dalam menulis. Kemudian autis, yang mana sulit mengendalikan sikap dan kebiasaan serta selalu berubah-ubah perilaku setiap harinya, namun mereka mampu mengikuti apa yang perintahkan kepadanya, dan cenderung lebih mengingat pesan apa saja yang di dapatnya di sekolah, namun harus di berikan ketegasan untuk mendisiplinkan anak autis. Dan ada juga penyandang tunadaksa, tulang kaki dan tangannya sangat rapuh, meski mampu menopang dirinya sendiri, namun sulit untuk berjalan dengan normal seperti yang lainnya, serta tangan kanannya kaku dalam melakukan aktivitas seharihari dan perlu terapi lanjutan yang ada di kelas khusus terapi tunadaksa di lingkungan yayasan tersebut, penyandang tunadaksa lebih mudah dalam proses pembelajaranya, karena daya ingat dan komunikasinya cenderung normal dan baik, hanya terjadi kelainan dalam pertumbuhan tulang saja. Dengan begitu guru harus dapat berkomunikasi dengan baik karena karakter dan kebutuhan mereka berbedabeda dalam satu kelas.

Saat penggalian data, peneliti mengelompokkan data hasil penelitian, hasil wawancara maupun dokumentasi setiap kali peneliti mendapatkan data. Hasil penelitian di susun berdasarkan pedoman pengamatan yang diuraikan sesuai situasi-situasi yang telah diamati. Sedangkan hasil wawancara dijabarkan sesuai penjelasan dari informan yang menjadi subjek dalam penelitian ini. Kemudian peneliti menggunakan sistem pengkodean penguraian dalam menjabarkan data yang diperoleh. 
Dibawah ini dijelaskan proses menganalisis data penelitian berupa pengamatan dan wawancara sebagai berikut. Ada empat kolom yang peneliti gunakan untuk membuat hasil pengamatan. Kolom pertama berisi kode, kolom kedua memuat bentuk kegiatan kelas atau lapangan, kolom ketiga tentang deskripsi pengamatan, subjek yang diamati, dan lokasi pengamatan berlangsung.

kolom ketiga tentang deskripsi pengamatan dibuat berdasarkan catatan yang ditulis dengan alat tulis. Dari catatan tanga tersebut kemudian peneliti menjabarkan dengan mendengar rekaman suara dan melihat beberapa video pengamatan saat guru kelas mengajar untuk mengingat kejadian pada saat itu. Kolom ke empat adalah keterangan, yang disususn berdasarkan indikator yang ada dalam pedoman pengamatan.

Tabel. 3. Analisis Data Berupa Hasil Pengamatan

\begin{tabular}{|c|c|c|c|}
\hline Kode & $\begin{array}{c}\text { Bentuk } \\
\text { Kegiatan }\end{array}$ & Deskripsi Pengamatan & Keterangan \\
\hline $\begin{array}{l}3007 . \\
\text { S2. }\end{array}$ & $\begin{array}{l}\text {-Opening } \\
\text { - } \\
\text { Pendampingan } \\
\text {-Menjadi } \\
\text { Mediator }\end{array}$ & 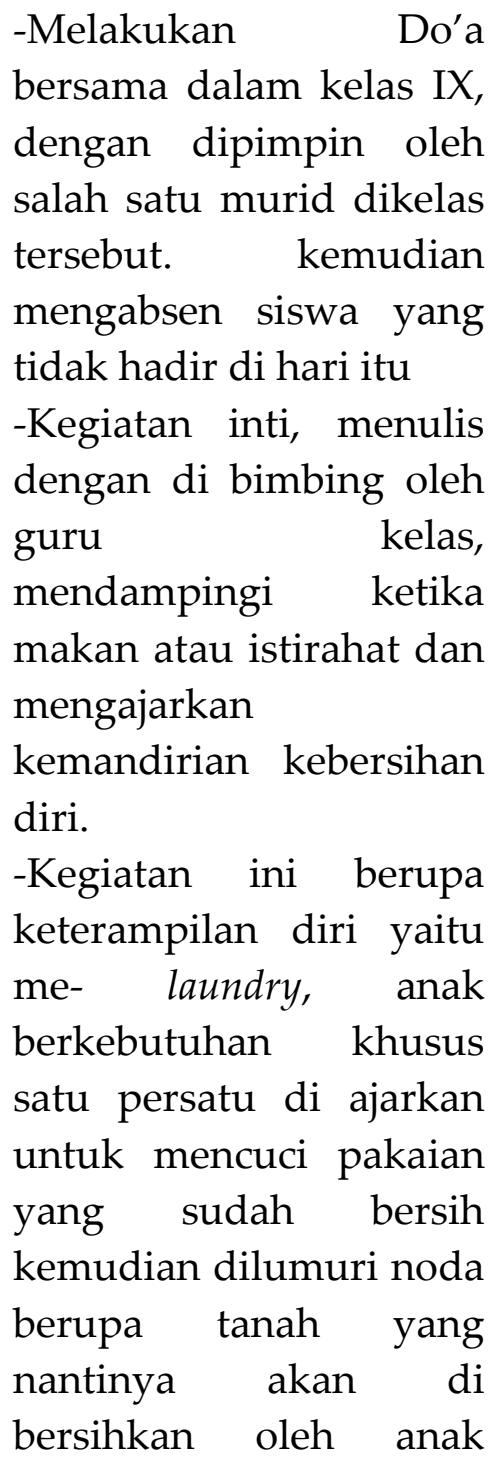 & $\begin{array}{l}\text { Dilakukan } \\
\text { dengan } \\
\text { pengawasan } \\
\text { guru kelas } \\
\text { dan } \\
\text { dilaksanakan } \\
\text { di kamar cuci. }\end{array}$ \\
\hline
\end{tabular}




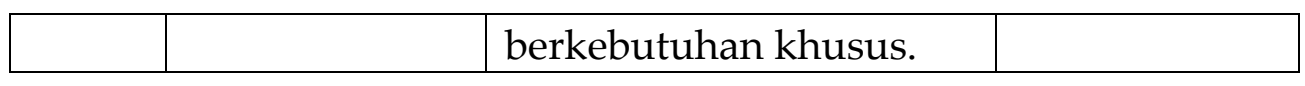

Tabel. 3 menunjukkan, bahwa subjek 2 melakukan kegiatan pendampingan juga pengawasan terhadap kegiatan. Menemani makan saat istirahat, mengatur ketertiban kelas dengan membuat peraturan kelas agar untuk di taati bersama-sama.

Pendekatan komunikasi pendidikan pada anak berkebutuhan khusus di lakukan secara individual berlangsung khusus tergantung kebutuhan mereka masing-masing setiap harinya. Ketika mengawali kegiatan pembelajaran DN mengajak siswa berdoa dengan mempersilahkan sala satu dari siswa kelasnya memimpin membaca surat Al-Fatihah, begitu juga dalam mengakhiri pembelajaran siswa diajak membaca do'a dan surat pendek Al-Ashr. Pada uraian diatas telah disinggung tentang perbedaan karakter siswa, maka tidak heran jika sering terjadi pertengkaran antar siswa ketika pembelajaran berlangsung. Jika hal itu terjadi makan tindakan yang dilakukan DN adalah melerainya dan menyuruh untuk meminta maaf dan berjabat tangan, dan berjanji untuk tidak mengulangi hal yang sama dikemudian hari. Dari sinilah komunikasi pendidikan bisa terjadi, dengan memahami karakteristik masing-masing siswa menjadi urgensi dalam keberhasilan komunikasi pendidikan pada anak berkebutuhan khusus di kelas IX.

Berikut hasil observasi yang menunjukkan kegiatan belajar mengajar. Pukul 07.30 bel berbunyi siswa masuk keruang kelas, bersama-sama dengan guru kelas masing-masing. Kemudian dikelas IX DN memberi salam dan mengajak berdoa dengan menyuruh salah satu diantara siswa untuk memimpin berdoa. Ketika itu materinya tentang Ilmu pengetahuan Alam. DN sebelumnya mengulang pembelajaran minggu lalu, yaitu tentang perubahan zat pada benda, dan memotivasi daya ingat siswa dengan memberikan pertanyaan benda apa saja yang berubah dari benda padat menjadi cair, dengan antusias siswa mengacungkan telunjuk mereka sambil menjawab dengan jawaban yang beragam sesuai pengetahuan mereka, ada yang jawabannya benar ada juga jawaban yang kurang tepat, namun semua itu cukup membangkitkan semangat mereka untuk mengingat dan mengulang pelajaran sebelumnya.

Kemudian DN melanjutkan materi tentang bagaimana cara menyelamatkan diri dari gempa bumi. Siswa pun menjawab dengan jawaban yang mereka ketahui, diantaranya ialah berlari, menyelamatkan diri, mengumpat di bawah meja, bahkan ada yang menjawab dengan cari mama. Setelah berhasil memotivasi siswanya, DN memberikan penjelasan tentang bagaimana cara menyelamatkan diri jika terjadi gempa bumi. Tanpa terasa terdengar bel berbunyi, maka saatnya istirahat tiba. Siswa diarahkan untuk membuka bekal yang sudah dibawanya dari rumah dan makan di dalam kelas secara bersama-sama. ${ }^{11}$

Pengamatan peneliti diatas, banyak ditemukan pendekatan yang dilakukan oleh DN dalam proses komunikasi pendidikan, mulai dari pembiasaan,

${ }^{11}$ Hasil observasi, dengan GK, tanggal 06 Agustus 2019 pada hari Selasa pukul 07.30-09.30 
pengalaman, emosional, dan keteladanan. Pengamatan peneliti sama halnya dengan yang diungkapkan DN saat dimintai keterangan mengenai komunikasi pendidikan pada anak berkebutuhan khusus. Berikut keterangan dari beliau:

"Pendekatan komunikasi bermacam-macam bu, pada kegiatan pembelajaran. Misalnya membiasakan mereka untuk membiasakan diri membaca do'a setiap hendak memulai pembelajaran dikelas, kemudian mendisiplinkan diri, untuk merapihkan alat tulis dan alat makannya masing-masing. Ya meski terkadang anak-anak itu suka diluar kebiasaan bahkan diluar kendali saat di sekolah. Dan dalam pembelajaran itu bukan hanya kognitifnya siswa yang dibangun akan tetapi kognitifnya juga, seperti tadi ada yang bertengkar maka guru harus menyuruh untuk saling meminta maaf, dan kejadian -kejadian yang diluar dugaan kita, maka kita harus memiliki kesigapan untuk mengkondisikan situasi tersebut, kadangkan anak-anak auti ini melakukan hal yang diluar kebiasaan mereka, jadi kita sebagai guru pun harus responsip dengan hal-hal yang bisa saja terjadi sewaktu-waktu. Kadang waktunya makan mereka berlari bahkan ada yang teriak-teriak smapi mengumpat di pojokan sana tuh. Mereka itu istimewa, dan harus diperlakukan istimewa juga menurut saya. Didalam kelas ini berbedabeda bu siswanya, yang 3 anak ini, mereka bida dididik bu, namun daya ingat pelajaran mereka rendah, berbeda lagi dengan 2 anak autis yang ini, mereka lebih mengingat apa yang di sampaikan, namun kebiasaan dan perilaku mereka harus telaten gurunya untuk bisa komunikasi dengan mereka dan menghadapi perilaku yang bisa kadang-kadang muncul tiba-tiba. Kalau yang 1 ini, dia agak lambat jika menagkap informasi dan perintah, harus lebih disertai tindakan untuk mengajarkannya." 12

Hasil wawancara diatas, menggambarkan adanya proses komunikasi pendidikan yang terjadi di dalam kelas pada anak berkebutuhan khusus. Seperti membiasakan mereka untuk terus berlatih menulis, berdoa. Dan yang paling penting tetap memperhatikan masing-masing karakter siswa dalam proses komunikasi pendidik terhadap anak berkebutuhan khusus.

Hal ini sesuai dengan prinsip teori interaksi yang dijelaskan dalam kajian teoretis menurut Herbert Blumer, yaitu Meaning, atau makna tidak inheren dalam objek namun berkembang melalui proses interaksi sosial antar manusia karena itu makna berada dalam konteks hubungan baik keluarga maupun masyarakat.

Hasil observasi dan wawancara di atas diperkuat dengan hasil domumentasi sebagai berikut.

12 Wawancara dengan GK, tanggal 06 Agustus 2019. 
Gambar. 1 Penyampaian Materi dengan komunikasi pendidikan pada anak berkebutuhan khusus.

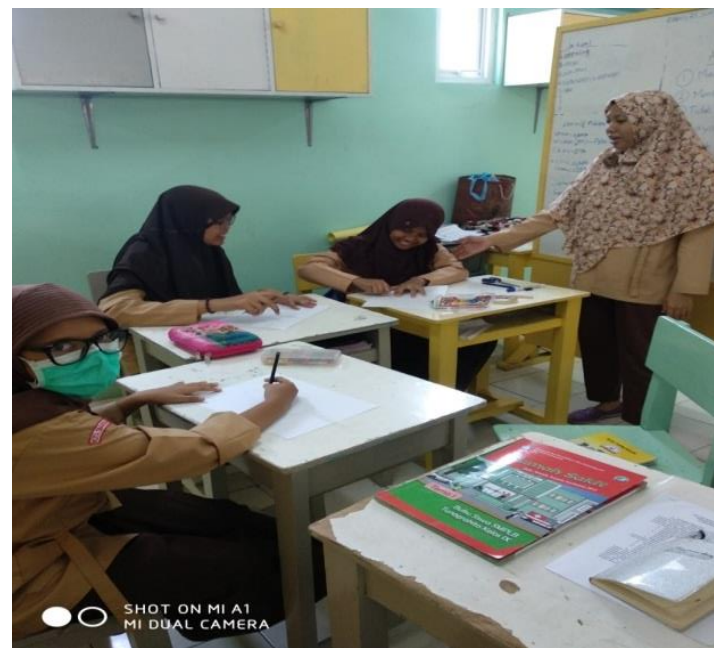

Mengenai perbedaan cara komunikasi juga dituturkan oleh ES selaku kepala sekolah di Sekolah Khusus Asy-Syifa Larangan Kota Tangerang. Yang menyatakan bahwa:

"Komunikasi pendidikan di sekolah kami memang terjadi secara individual bu, dikarenakan dalam satu kelas itu terdiri dari berbagai macam anak berkebutuhan khusus, jadi tidak hanya satu karakteristik kekhususan saja. Karena dengan cara seperti itu, kami lebih mudah berinteraksi dan komunikasi dengan memahami individu atau karakteristik anak masing-masing. Jadi tidak dengan klasikal dalam memahami komunikasi mereka, it tetap harus perindividu, karena dari emosional, pemahaman, dan kebutuhan anak dalam satu kelas itu tidak sama atau berbeda-beda."13

Dari hasil wawancara diatas, sesuai dengan teori interaksi simbolis dengan konsep pentingnya konsep diri (self). yang mana mengasumsikan bahwa konsep diri dikembangkan melalui interaksi dengan orang lain dan memberikan motif dalam berperilaku. Yaitu merupakan persepsi diri sendiri yang bersifat psikologi, sosial, dan fisik yang diperoleh melalui pengalaman dan interaksi denga orang lain. Dapat disimpulkan komunikasi pendidik terhadap anak berkebutuhan khusus di sekolah Asy-Syifa Larangan ini memang terjadi secara Individual, dikarenakan kebutuhan dan pemahaman setiap anak berkebutuhan dalam satu kelas itu tidak sama.

Tidak berhenti sampai disitu, peneliti kemudian melanjutkan observasi berikutnya pada kegiatan yang berdeda, yakni kegiatan intra diantaranya kegiatan seni menari. Pada kegiatan ini DN pula yang melatih siswa-siswa kelas IX untuk berlatih menari di dalam ruangan kelas, dengan di putarkan musik yang telah disepakati untuk latihan menari, dan anak-anak begitu sangat antusias mengikuti kegiatan tersebut. DN membimbing kegiatan menari dengan mengunakan intruksi sebagai panduan gerakan siswa, untuk anak penyandang tunadaksa disediakan

${ }^{13}$ Hasil wawancara dengan kepala sekola Khusus Asy-Syifa, 06 Agustus 2019 
bangku khusus untuk mereka yang memang tidak mampu berdiri. Dalam kegiatan tersebut anak-anak tersenyum dan bergembira mengikuti alunan musik sambil menari di dalam kelas. Kemudian sambil memantau anak-anak menari DN menerangkan bahwa:

"Kegiatan menari seperti ini bu, adalah kegiatan yang paling mereka sukai, karena mungkin dengan mereka mendengar musik kemudian bernyanyi dan menari itu bisa memperbaiki goodmood mereka setelah belajar di kelas, karena ada siswa saya yang jika ia diberi tugas dia itu langsung pusing karena lelahnya berfikir dan mengingat, itu terjadi pada anak berkebutuhan seperti anak autis. Maka dari itu dengan adanya kegiatan ini, mereka sangan responsif dalam mengikutinya, walau pun gerakan mereka belum sempurna, tetapi itu cukup membuat emosional dan hormon bahagia mereka bekerja."

Dari hasil wawancara diatas sejalan dengan konsep teori simbolik pentingnya makna bagi perilaku manusia yang mengasumsikan bahwa makna diciptakan melalui interaksi dan modifikasi melalui interprestasi. Teori ini juga mengasumsikan bahwa bagaimana manusia berinteraksi dengan manusia lainnya tergantung pada makna yang diberikan oleh manusia lainnya. Komunikasi yang efektif tidak akan terjadi tanpa adanya makna yang dibagikan. Seperti halnya hasil wawancara diatas maka peneliti berasumsi, mengenai konsep interaksi simbolik ini sangatlah sesuai dengan hasil wawancara diatas.

Kemudian dilanjutkan observasi di hari berikutnya yaitu tanggal 07 agustus 2019, Ketika itu kegiatan mereka ialah sedang istirahat dan menyantap bekal makanan masing- masing yang telah dibawanya dari rumah.

Gambar 2. Kegiatan makan bersama di kelas

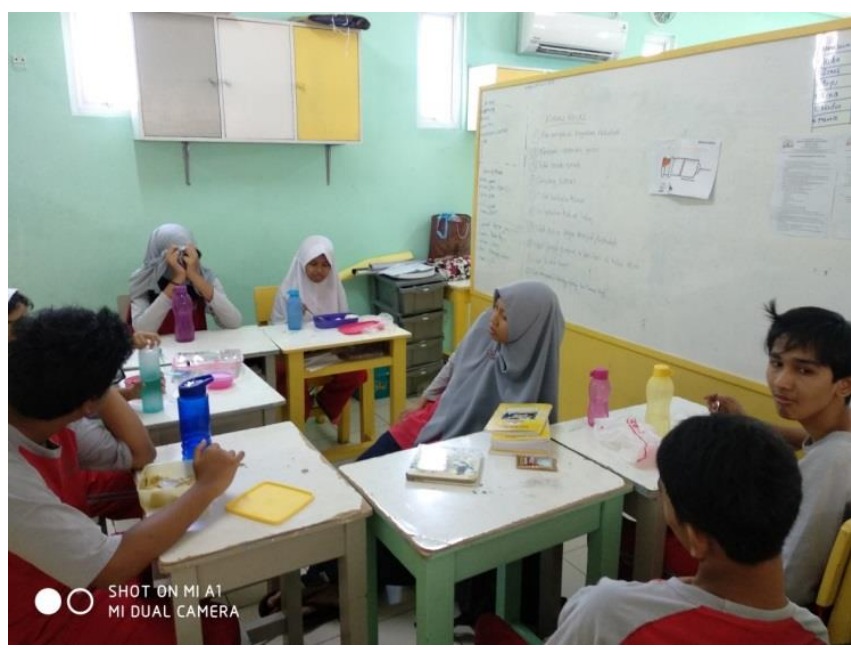

Pada gambar 2, para siswa kelas IX sedang makan bersama pada jam istirahat. Mereka membawa bekal makanannya sendiri dari rumah, dan diperiksa oleh guru kelas, jika ada makanan yang dilarang untuk bekal seperti makanan yang mengandung MSG, formalin, atau kandungan zat berbahaya bagi kesehatan anak 
dan sebagainya maka akan di kembalikan dan diberikan catatan di buku penghubung komunikasi siswa sebagai peringatan bagi orang tua untuk tidak mengulangi membawakan beka yang tidak di perbolehkan dibawa ke sekolah. Seperti yang telah disampaikan Ibu Dina:

“Terkadang orang tua pun sering lupa, padahal sudah sering kali kami ingatkan melalui buku komunikasi siswa atau pun jaringan pribadi agar tidak membawakan bekal yang sudah di tetapkan, seperti junkfood, cokelat dan makanan berbahan kimia lainnya, namun tetap saja kebijakan itu tidak diindahkan oleh orang tua sendiri bu, padahal itu untuk kebaikan anak-anak juga". ${ }^{14}$

Dari hasil wawancara diatas ternyata masih kurangnya peran atau kerja sama antara pendidik di sekolah dan orang tua yang mendidik anak-anaknya di rumah, dan hal ini bertentangan dengan konsep teori interaksi simbolik pada hubungan antara individu dan masyarakat, yang mengasumsikan bahwa konsep budaya da proses sosial mempengaruhi manusia dan kelompok atau karenanya struktur sosial ditentukan melalui jenis-jenis interaksi sosial. Teori ini mempertimbangkan bagaimana norma masyarakat dan budaya menjadi perilaku individu.

Kegiatan pada gambar 3, menjelaskan kegiatan para siswa-siswi Sekolah Khusus Asy-Syifa dalam memakai dan mengikat sepatunya masing-masing ketika hendak sebelum bel pulang berbunyi.

Gambar. 3. Siswa-siswa berlatih memakai dan mengikat sepatunya masing-masing.

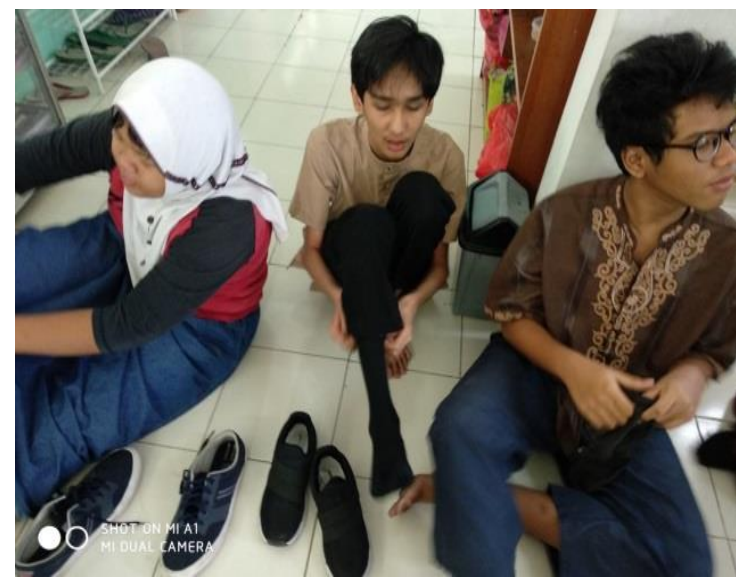

Disini merupakan kegiatan pembiasaan kemandirian diri, tidak sedikit anak berkebutuhan belum bisa membiasakan untuk dirinya sendiri, dan di Sekolah Khusus Asy-Syifa di terapkan yang utama ialah tentang kemandirian untuk anak berkebutuhan khusus.

Hal tersebut sesuai dengan prinsip teori ineraksi simbolik, yaitu Thought adalah pemikiran berimplikasi kepada interprestasi yang diberikan seseorang

${ }^{14}$ Wawancara dengan Ibu dina selaku guru kelas IX Sekolah Khusus Asy-Syifa, Rabu 07 Agustus 2019. 
terhadap simbol. Pemikiran termasuk imaginasi yang memiliki kekuatan untuk menyediakan gagasan walaupun tentag suatu yang tidak diketahui berdasarkan pengetahuan yang diketahui. Misalnya berfikir.

Begitu pula hal yang diungkapkan guru kelas ketika peneliti mewawancarai perihal kemandirian siswa-siswi kelas IX:

"Di dalam kegiatan sehari-hari untuk anak-anaak ini, kami lebih memfokus kan kepada kemandirian diri siswa, seperti merapihkan alat belajr ke dalam tas, kemudian mencuci piring dan alat makan, lalu, cara membersihkan diri sendiri, seperti menggosok gigi setelah makan, lalu mengelap kaca, bahkan mengikat sepatu sendiri pun mereka harus masih dituntun atau diajarkan bu, karena masih ada beberapa anak berkebutuhan khusus, contohnya sepetti Valen, yang memiliki kebutuhan khusus Tunagrahita, itu dia tidak bisa hafal untuk mengingat bagaimana membuat simpul pada mengikat tali sepatunya sendiri" 15

Maka peneliti menyimpulkan, dengan adanya kegiatan seperti digambar, itu sangatlah membantu untuk mengasah kemandirian para siswa berkebutuhan khusus, terlebih untuk kemandirian diri mereka masing - masing. Dan hal ini pun sudah selaras dengan prinsip teori interaksi simbolik.

Pada kegiatan dihari berikutnya, peneliti mengambil dokumentas untuk memperkuat bahan penelitian di dalam penulisan ini. Kegiatan pada gambar 4, dibawah menerangkan aktivitas di dalam kelas bersama ibu Dina selaku wali kelas IX, para siswa-siswi diajarkan mewarnai gambar sesuai dengan perintah yang di anjurkan wali kelas. Dan tugas di kumpulkan jika sudah selesai.

Gambar 4. Kegiatan mewarnai gambar dikelas bersama dengan guru kelas IX ( Ibu Dina )

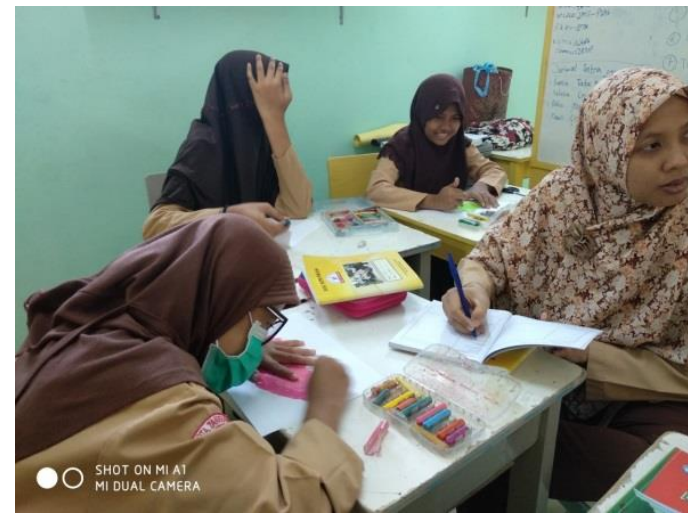

Pada kegiatan diatas guru kelas sedang menuliskan buku komunikasi siswa, yaitu tentang kegiatan dan pesan untuk orang tua agar dapat bekerja sama dalam perkembangan dan kemajuan anaknya. Cara seperti sangat diperlukan agar orang tua pun mengerti apa saja yang dialami anaknya selama berada di sekolah. demikian pemaparan menurut guru kelas juga kepala sekolah.

${ }^{15}$ Wawancara dengan Guru Kelas (Ibu Dina) di ruangan kelas, 07 Agustus 2019. 
Karena jika terjalin komunikasi yang baik antara guru di sekolah dan orang tua di rumah akan sangat berdampak positif untuk perkembangan komunikasi anak berkebutuhan khusus dalam pembelajarannya sehari-hari. namun di sekolah Khusus Asy-Syifa kerja sama semacam ini masih minim terjalin, penyebab dari hal itu ialah biasanya orang tua merasa kasihan karena anak nya telah banyak belajar di sekolah, kemudian ketika di rumah kebiasaan atau perilaku yang sudah diajarkan para pendidik di sekolah terkadang tidak diterapkan di rumah atau tidak diingatkan pula kepada anak-anaknya apa saja hal yang telah didapatnya dari sekolah.

\section{Strategi komunikasi pendidik pada anak berkebutuhan Khusus di sekolah Khusus Asy- Syifa}

Strategi komunikasi pendidik kepada peserta didik berbeda-beda tergantung pada kondisi peserta didik, dalam hal ini strategi yang dilakukan pendidik untuk membuat para peserta didik dikelas IX semakin ingin melakukan perintah pendidik adalah dengan memberikan simulus berupa pujian dan ungkapan kasih sayang pada peserta didik. Ketika peserta didik menerima simulus yang positif makan akan membuat peserta didik merasa lebih nyaman dan tenang. Peserta didik yang ada di dalam kelas IX terdiri dari berbagai macam kebutuhan khsus, diantaranya tunagrahita, autis dan tunadaksa, yang pada masing- masing kebutuh memiliki priotitas khusus dalam komunikasi itu sendiri. Oleh karena itu pendidik harus sabar, penyayang, mengajar dengan kata-kata sederhana. Setiap pendidik akan memberikan strategi pembelajaran dan komunikasi yang sesuai dengan masingmasing kemampuan peserta didik.

Strategi komunikasi anak berkebutuhan khusus tuna grahita yang memiliki kelemahan seperti pelupa, sulit memahami apa yang disampaikan dan perhatian yang mudah terganggu, tidak akan sama dengan komunikasi anak berkebutuhan tuna daksa, yang dari segi mental dan otaknya normal hanya saja memiliki keterbatasan fisik sehingga memerlukan layanan khusus dan alat bantu gerak, agar mereka bisa melakukan aktifitas sehari-hari tanpa adanya bantuan orang lain. Media pembelajaran atau strategi yang digunakan untuk peserta didik tunadaksa sama dengan anak normal lainnya, tidak ada strategi khusus karena yan bermasalah pada anak tunadaksa hanyalah faktor fisik saja. Berdasarkan hasil penelitian setiap peserta didik memiliki kemampuan dan gangguan yang berbeda sehinga penanganan tidak dapat fokus pada satu metode saja.

Menurut Ibu Dina wali kelas IX di sekolah Khusus Asy-Syifa Larangan menyatakan bahwa:

"Pendidik harus menyesuaikan kemampuan peserta didik dalam proses pembelajaran, dan komunikasi, karena kemampuan dan gangguan yang dimiliki peserta didik berbeda-beda dan pendidik harus selalu mencari strategi agar peserta didik cepat tanggap dengan memperlihatkan gambar dan contoh yang akan disampaikan. Pendidik akan memberikan strategi komunikasi pembelajaran berdasarkan kondisi dan situasi tertentu. Sehingga diharapkan 
dengan cara yang berbeda agar didapatkan perkembangan maksimal dari masing-masing peserta didik". ${ }^{16}$

Pendidik menggunakan komunikasi interpersonal agar peserta didik mampu untuk memahami bahasa yang diajarkan oleh pendidik untuk pelajaran dan komunikasi dengan lingkungannya, dan pendidik mampu untuk mengenal peserta didik secara pribadi. Hal ini sejalan dengan yang telah diuraikan sebelumnya bahwa komunikasi inter personal adalah interaksi dua orang yang berlangsung secara tatap muka (komunikasi diadik) komunikasi dengan tatap muka dan dua arah sangat efektif untuk kelangsungan belajar, sehingga dapat langsung menerima umpan balik dari pendidik dan peserta didik.

Layanan pendidikan yang digunakan lebih banyak menggunakan layanan face to face (tatap muka), karena di sekolah khusus tidak mungkin menggunakan sistem klasikal, hal itu disebabkan oleh sekolah berkebutuhan khusus perlu penanganan khusus dan yang lebih banyak diterapkan yaitu bimbingan perorangan. Kalau di sekolah umum, pendidik bisa sambil melatih berbicara membelakangi peserta didik. Sedangkan jika dibandingkan dengan sekolah berkebutuhan khusus tidak bisa seperti ti, pendidik harus langsung bertatap muka kemudian mimiknya harus jelas, dan lebih banyak lagi hal yan harus diperhatikan dalam melayani mereka.

Untuk menerapkan komunikasi yang baik, pendidik melakukan pendekatan interpersonal dengan berkomunikasi secara tatap muka langsung agar memungkinkan peserta didik mudah menerima pesan atau pun pelajaran dan informasi yang disampaikan pendidik. Peserta didik pun menerima dan merespon pendidik dengan perhatian yang baik. Sehingga komunikasi yang terjalin bisa berjalan dengan baik sesuai yang diharapkan oleh pendidik dari awal melakukan pendekatan interpersonal.

Komunikasi kelompok kecil tidak diterapkan, karena di dalam ruang kelas IX anak berkebutuhan khusus digabungkan yaitu tuna grahita, tuna daksa, autis dan down syndrome. Pembelajaran tidak efektif jika pendidik mengajar dengan menggunakan komunikasi kelompok kecil.

Berdasarkan hasil penelitian, pendidik akan melakukan interaksi dengan peserta didik dengan memunculkan ikatan sehingga peserta didik dapat memberikan makna dari setiap pesan yang ditunjukkan peserta didik. Pendidik menunjukkan kasih sayang yang dapat menyebabkan para pendidik lebih responsif dan pendidik akan semakin memahami peserta didik dan akan semakin terbuka dalam mengungkapkan keinginannya. Komunikasi yang berlangsung antara pendidik dengan peserta didik akan terus mengalami perkembangan seiring proses pembelajaran berlangsung. Adanya ikatan yang terjadi akan menyebabkan anak merasa lebih nyaman berada di lingkungan bersama pendidik yang menyayanginya. Pendidik juga akan menunjukkan sikap marah dan suara lantang saat peserta didik tidak mau menurut atau melanggar aturan yang telah diberikan serta pembelajaran

16 Wawancara dengan guru kelas IX(ibu Dina) di ruang kelas, 07 Agustus 2019. 
akan disampaikan pendidik dengan ketegasan sehingga peserta didik dapat disiplin pada waktu yang telah ditentukan sehingga peserta didik akan memahami kapan waktu istirahat dan pulang.

Interaksi antara pendidik dan peserta didik akan muncul pemahaman yang berbeda diantara keduanya dalam memahami sikap masing-masing. Peserta didik tidak dapat memahami apa yang disampaikan pendidik dalam waktu yang singkat. Pendidik juga harus mempelajari karakteristik peserta didik sehingga mengerti apa yang peserta didik inginkan dan apa yang tidak disukai peserta didik. Seorang pendidik anak berkebutuhan khusus juga akan belajar dari pengalamanpengalaman yang telah dilalui, sehingga pendidik akan menentukan sikap yang tepat dalam menghadapi anak pada kondisi-kondisi tertentu. Satu metode pembelajaran belum tentu cocok untuk semua anak, karena setiap anak memiliki karakteristik, gangguan, dan kemampuan yang berbeda.

Komunikasi nonverbal yang digunakan di sekolah ini berupa gerakan anggota tubuh, seperti tatapan mata, tepukan di punggung, artikulasi saat berbicara, senyuman, isyarat-isyarat anggota tuhun untuk mempertegas maksud yang ingin diutarakan, dan lain-lain. Pendidik juga menggunakan komunikasi verbal yang digabung dengan komunikasi nonverbal. Oleh karena itu, komunikasi verbal dan nonverbal berperan sekali dalam komunikasi pendidik dalam mengajar peserta didik. jadi, dalam mengajar pendidik menggunakan komunikasi secara personal atau face to face. Misalnya, salah satu peserta didik saat kegiatan belajar mengajar anak terebut tidak memahami perintah soal yang diberikan maka pendidik tersebut akan secara intends mendekati dan membantu mengerjakan soal tersebut. Sedangkan anak yang lainnya juga diperhatikan. Komunikasi verbal merupakan salah satu bentuk komunikasi yang lazim dipergunakan untuk menyampaikan pesan -pesan kepada pihak lain melalui tulisan maupun lisan. Di dalam proses ini komunikasi yang dilakukan oleh pendidik di sekolah khusus Asy-Syifa di Larangan pada kenyataannya menggunakan komunikasi verbal dan non verbal, hal ini terlihat dari beberapa hasil wawancara dengan pendidik di sekolah tersebut.

Berkomunikasi dengan anak berkebutuhan khusus akan sangat berbeda dengan anak normal biasanya, apa bila berkomunikasi dengan anak normal tentunya akan lebih mudah terjadi karena cara pemahaman mereka lebih cepat memahami maksud dari communicator tentang pesan yang disampaikan, perbedaan yang mencolok akan terlihat dan menjadi hambatan komunikasi apabila proses komunikasi terjadi pada peserta didi. Komunikasi verbal merupakan bentuk komunikasi yang sering digunakan oleh pendidik di sekolah khuss Asy-Syifa di Larangan.

Bentuk kedua yang digunakan oleh pendidik dalam berinteraksi dengan peserta didik adalah dengan bentuk komunikasi nonverbal. Dalam komunikasi nonverbal, kinesik, atau gerakan tubuh, meliputi kontak mata, ekspresi, wajah, isyarat, dan sikap tubuh. Gerakan tubuh biasanya digunakan untuk menggantikan suatu kata atau frasa, misalnya mengangguk untuk menyatakan iya, untuk 
mengilustrasikan atau menjelaskan sesuatu, menunjukkan perasaan, misalnya memukul meja untuk menunjukkan kemarahan, untuk mengatur dan mengendalikan jalannya percakapan.

Sesuai dengan bentuk komunikasi interpersonal yang diuraikan sebelumnya, yang terbagi atas komunikasi verbal dan non verbal, pendidik telah berusaha mempraktikkannya dnegan baik kepada peserta didik sehingga komunikasi interpersonal dapat lebih terjadi dengan baik.

Hasil penelitian yang ditemukan melalui wawancara langsung dengan pendidik mengenai strategi komunikasi interpersonal pendidik dengan peserta didk dalam prose belajar di sekolah Khusus Asy-Syifa di Larangan sangat perlu dilakukan oleh pendidik, disebabkan sering kali pada anak berkebutuhan khusus tersebut harus didekati secara individu, untuk memberikan pengetahuan atau pengajaran kepada mereka bisa tercapai. Pendekatan pribadi dengan mengajak bercerita secara individu, kemudian pendekatan komunikasi persuasif dengan bujukan selalu dilakukan oleh pendidik Sekolah Khusus Asy-Syifa.

Hasil penelitian diatas telah sesuai dengan yang digunakan peneliti sebagai landasan teori interaksi simbolik dalam penelitian ini dimana para pendidik berusaha membentuk aturan, cara atau strategi berkomunikasi dengan peserta didik dengan mempertimbangkan segala sesuatu yang menjadi acuan untuk berkomunikasi dengan peserta didik anak berkebutuhan khusus juga diperlukan kriteria-kriteria khusus diantaranya: kesabaran, keuletan, kedisiplinan, ketertiban, kreativitas, yang tinggi serta kepribadian yang baik. Karena anak berkebutuhan khusus ini adalah anak yang memiliki memiliki kelainan mental dan memiliki latar belakang kepribadian yang berbeda dengan anak normal pada umumnya, kelainan mental yang dialami peserta didik tersebut memberikan dampak dalam berkomunikasi dan berinteraksi dengan orang lain. Peserta didik tunagrahita dan autis menggunakan simbol-simbol dalam berkomunikasi dan berinteraksi dengan orang lain maupun teman sebayanya. simbol-simbol ini biasanya digunakan peserta didik gerakan-gerakan anggota tubuh seperti tangan, mata, dan anggota tubuh lainnya.

Menurut Ibu Dina wali kelas IX mengatakan bahwa:

"Pendidik berusaha untuk mengetahui apa yang dialami peserta didik tunagrahita, tunadaksa, autis, ada rasa ingin memaknai apa yang dialami peserta didik rasakan sehingga tercipta rasa terbeban untuk mendidik peserta didik. kemudian adanya sikap mendukung adanya konsep seperti ini pendidik berusaha semaksimal mungkin memberikan semangat terhadap anak misalnya, mengatakan "kamu ganteng", "kamu pinter" . Selanjutnya sikap positif, seorang pendidik menanamkan sikap positif dalam dirinya, menanamkan konsep diri kepada peserta didik bahwa anak berkebutuhan khusus bukanlah anak yang tidak berguna, tapi dengan banyak belajar anak berkebutuhan khusus bisa jadi orang yang membanggakan dikemudian hari". ${ }^{17}$

${ }^{17}$ Hasil wawancara dengan Guru kelas (Ibu Dina), 07 Agustus 2019, pukul 09.45 WIB 
Dalam komunikasi itu di perlukan interaksi yang berkesinambungan, antara informan dan subjek, jika salah satu dari aspek tersebut tidak sinkron maka akan terjadi mist atau kesalahfahaman dalam komunikasi itu sediri. Ketika komunikasi itu sendiri berlangsung dengan anak berkebutuhan khusus sudah pasti akan ada perbedaan dengan halnya anak-anak normal lainnya. Maka dari itu butuh strategi atau cara yang tepat untuk berkomunikasi dengan anak-anak berkebutuhan khusus. Berikut penelitian yang telah peneliti dapatkan dalam strategi komunikasi yang digunakan dalam komunikasi pendidik terhadap anak berkebutuhan khusus.

Dari beberapa kegiatan diatas dapat disimpulkan, kegiatan sehari-hari yang di terapkan ialah mengenai proses kemandirian dan keterampilan untuk siswa kelas IX. Yang masih diperlukannya bimbingan dan pembiasaan baik di rumah maupun di sekolah.

Dalam komunikasi pendidikan anak berkebutuhan khusus diperlukan pemahaman yang baik dalam mengkomunikasikan apa yang akan disampaikan, karena dalam penyampaian informasi atau pesan anak-anak berkebutuhan khusus tidak mudah, satu sama lainya berbeda, setiap anak berbeda dalam penyampaian pesan pendidikan.

Komunikasi dapat dibentuk melalui empat macam pengondisian atau pembelajaran: Pertama, pengondisian klasikal yakni pengondisian dapat terjadi saat rangsangan atau stimulus diikuti dengan rangsangan atau stimulus yang lain yang muncul, yang menjadikan stimulus pertama sebagai landasan signal untuk stimulus berikutnya; Kedua, pengondisian instrumental yakni kebiasaan dari hasil belajar yang muncul saat suatu tingkah laku memunculkan respon yang menyenangkan bagi seseorang, oleh karena itu tingkah laku tersebut akan diulangi kembali. Namun, lain halnya ketika tingkah laku yang menyebabkan sesuatu yang tidak menyenangkan bagi seseorang maka tingkah laku tersebut tidak tidak akan diulangi lagi atau dihindari; Ketiga, pengondisian atau pembelajaran berdasarkan pengamatan yang dapat diartikan sebagai proses berprilaku dari kebiasaan mengamati perilaku orang lain, lalu dijadikannya sebagai contoh untuk melakukan tindakan yang sama; Keempat, yakni perbandingan sosial yaitu proses pembelajaran atas dasar perbandingan dengan orang lain untuk melihat kebenaran dan kesalahan dari pandangan diri sendiri dengan orang lain. Orang lain yang menjadi dasar acuan untuk mengambil sebuah tindakan, melihat dari ide-ide atau pandangan orang lain lalu menyama rata kan sebagai dasar mengambil sebuah tindakan atau sikap. Kemudian dari pembentukan dan perubahan sikap akan menghasilkan dua kondisi sikap yang berbeda yakni sikap positif dan sikap negatif.

a. Sikap Positif

Sikap positif dari orang tua terhadap anak penyandnag berkebutuhan khusus, peneliti temukan dari 4 subjek penelitian di Sekolah Khusus Asy-Syifa. Sikap positif tersebut dimunculkan dari berbagai macam hasil pengondisian sikap dan komunikasi yang kaitannya dengan perubahan dan pembentukan sikap. Karena pada dasarnya sikap bukanlah sesuatu hal yang muncul dengan sendirinya 
tanpa ada proses-proses pembentukan dan bukan pula sesuatu yang telah melekat dalam diri manusia sejak ia dilahirkan. Sikap dibentuk melalui proses belajar sosial yaitu proses dimana individu memperoleh informasi, tingkah laku atau sikap baru dari orang lain. ${ }^{18}$

Sikap dibentuk melalui tiga macam bentuk pengondisian atau pembelajaran berdasarkan pengamatan dan proses pembelajaran atau dasar perbandingan. ${ }^{19}$ Sikap positif yang dimunculkan oleh orang tua dibuktikan dengan adanya peran da tindakan -tindakan yang dilakukan untuk kebaikan anaknya, misalkan dengan membawa anaknya ketempat terapi berjalan. Tindakan lainnya ialah memasukan anknya ke sekolah luar biasa untuk anak berkebutuhan khusus seperti Sekolah Khusus Asy-Syifa. Dengan upaya-upaya yang dilakukan orang tua tetap memilki kepercayaan bahwa anaknya masih bisa untuk diberikan pendidikan dan hak seperti anak pada umumnya. Orang tua juga bertindak dengan kesadaran penuh dan kesabaran memahani kondisi anak yang sulit menerima beberapa usaha yang dilakukan orang tua karena kekurangan yang dimiliki oleh sang anak dalam berkomunikasi atau pun merespon dan berinteraksi.

b. Sikap Negatif

Sikap negatif orang tua terhadap anak penyandang kebutuhan khusus peneliti tidak temukan di Sekolah Khusus Asy-Syifa. Tentunya dalam komunikasi pendidikan anak berkebutuhan khusus para oran tua dan guru harus memiliki optimisme dalam perkembangan anak tersebut.

(1) Faktor - Faktor pendukung dan penghambat penerapan Strategi Komunikasi pendidik pada anak berkebutuhan khusus di Sekolah Asy-Syifa

Strategi pembelajaran merupakan cara khusus yang dilakukan pendidikan untuk dapat memberikan pemahaman pada peserta didik sehingga peserta didik dapat mencapai tujuan pembelajaran. Ada beberapa faktor yang bisa menjadi pendukung dan penghambat untuk pendidik dalam merencanakan strategi pembelajaran seperti:

a. Faktor Pendukung

1). Pendidik selalu memberi motivasi dan kasih sayang

Hal ini sangat berperan pada kemajuan dan perkembangan peserta didik selanjutnya melalui proses belajar. Selama pembelajaran, pendidik sering kali memberikan motivasi dalam bentuk verbal dan non verbal. Motivasi yang diberikan juga berupa motivasi positif agar peserta didik tetap bersemangat dalam mengikuti pelajaran. Contoh dari motivasi verbal yaitu pujian dari pendidik seperti "iya pintar" "iya begitu benar", "ayo diteruskan", dan lain-lain. Sedangkan motivasi non verbal yang peneliti temukan antara lain: pendidik

18 Sarlito W.S. Eko A.M. Psikologi Sosial.(Jakarta: Salemba Humanika.2011)h. 84-85

${ }^{19}$ Sarlito W.S. Eko A.M. Psikologi Sosial (Jakarta: Salemba Humanika.2011), 84-85. 
selalu menyampaikan materi dengan tersenyum pada saat peserta didik kesulitan pendidik menjelaskan lagi dengan tersenyum, pendidik membelai rambut anak didiknya dan mengajak anak melakukan tos pada saat peserta didik dapat mengerjakan dengan benar.

Bila motivasi pendidik tepat mengenai sasaran akan meningkatkan kegiatan belajar. Dengan begitu, peserta didik akan belajar lebih tekun, lebih giat dan bersemangat. Bentuk motivasi lain yang diberikan adalah berupa pujian-pujian yang bisa membangkitkan semangat peserta didik untuk belajar, dan penghargaan pada peserta didik berupa makanan ringan atau hadiah kecil, pendidik juga memberi kasih sayang secara individual. Didalam hal ini, pendidik mengajar dengan rasa kasih sayang. Para pendidik pun sudah menganggap peserta didik sebagai anaknya sendiri. Menurut mereka, jika mengajar dengan hati dan kasih sayang maka terjalinlah hubungan yang dekat. Berdasarkan hal tersebut diatas menunjukan bahwa pendidik berupaya menerapkan komunikasi interpersonal dengan baik.

\section{b. Faktor Penghambat}

1). Kurangnya ruang kelas dan tenaga pendidik

Kuranngnya ruang kelas yang memadai dimana anak tunagrahita, tuna daksa dan autis ditempatkan dalam satu ruangan. Sehingga ini menimbulkan ketidak fokusan peserta didik apalagi anak tuna grahita yang memerlukan penanganan khusus dalam proses belajarnya. Menurut Ibu Evi kepala sekolah Sekolah Khusus Asy-Syifa mengatakan bahwa:

"Dampak masih kurangnya ruang kelas terpaksa proses belajar mengajar dilakukan dalam satu ruangan, bila dibandingkan dengan jumlah peserta didik yang ada saat ini, keberadaan ruang kelas jauh dari kebutuhan jumlah peserta didik yang ada. Untuk ruangan ini kita masih ada keterbatasan maka anakanak belajar masih digabung. Selain masih kekurangan ruang belajar, sekolah khusus Asy-syifa ini juga memiliki kekurangan tenaga pengajar guru. Idealnya Sekolah berkebutuhan Khusus ini bisa menampung semua peserta didik berkebutuhan khusus, namun karena keterbatasan ruang kelas serta tenaga pendidik secara otomatis kondisi tersebut akan berdampak terhadap pemenuhan kebutuhan peserta didik termasuk belajar peserta didik" ${ }^{20}$

Terkait kekurangan tenaga pendidik, kepala sekolah Sekolah Khusus Asysyifa mengaku pernah mengajukan permohonan penambahan akan tetapi keterbatasan spesifikasi pendidik PLB serta belum adanya pengangkata PNS dari pormasi PLB permohonannya belum terpenuhi.

2). Gangguan mental yang dimiliki peserta didik

Gangguan mental yang dimiliki oleh peserta didik juga menyebabkan pembelajaran yang disampaikan pendidik tidak dapat berlangsung secara efektif.

${ }^{20}$ Wawancara dengan kepala sekolah( ibu Evi) ,di ruang guru, 08 agustus 2019. 
Peserta didik tunagrahita memiliki kelemahan dalam berfikir, akibatnya dari kelemahan tersebut anak tunagrahita mempunyai kemampuan belajar dibawah rata-rata. Sehingga ini membuat pendidik harus mengulang-ulang hingga peserta didik paham tehadap materi yang disampaikan. setiap anak memiliki keterbatasan yang pendidik harus menghadapi peserta didik agar pembelajaran dapa berlangsung dengan baik.

\section{KESIMPULAN}

Dari kesimpulan pembahasanskripsi yang berjudl Komunikasi Pendidik Pada Anak Berkebutuhan Khusus disekolah Khusus Asy-Syifa adalah: 1) Bahwa komunikasi pendidikan di sekolah Khusus Asy-Syifa sudah baik, antara pendidik terhadap peserta didik. Komunikasi berlangsung secara indivdual tidak secara klasikal dikarena kan kemampuan dan pemahaman setiap siswa dalam satu kelas tidak sama atau berbeda-beda; 2) Strategi yang digunakan oleh guru kelas IX dalam pelaksanana kegiatan pembelajaran untuk komunikasi pendidikan anak berkebutuhan khusus ialah dengan cara pendekatan individual, secara khusus mengenali karakteristik atau sifat anak berkebutuhan khusus tersebut. Hal ini seperti terdapat dalam interaksi simbolik yang terdiri dari, Ego Sequal, Insequere, dan rasa ingin tahu yang tinggi.

Berdasarkan deskripsi hasil penelitian, pembahasan dan kesimpulan diatas dapat diuraikan beberapa saran yan ingin peneliti sampaikan mengenai komunikasi pendidikan anak berkebutuha khusus yang ada di Sekolah Khusus Asy-Syifa Larangan sebagai berikut: 1) Saran Akademis. Diharapkan adanya kurikulum khusus untuk tunarungu, ksehingga dapat lebih memaksimalkan program di Sekolah Khusus Asy-Syifa untuk anak penyandang berkebutuhan khusus; 2) Saran Umum. meski dengan adanya sekolah berkebutuhan khusus, bagi masyarakat umum pun dapat membantu proses komunikasi dengan anak-anak berkebutuhan khusus, yaitu dengan aspek interaksi sosial yang dibangun di lingkungan sekitar. 


\section{DAFTAR PUSTAKA}

A.M. Sarlito W.S. Eko, Psikologi Sosial. Jakarta: Salemba Humanika. 2011.

Fatoni, Abdurahman, Metodologi Penelitian dan Teknik Penyusunan Skripsi. Jakarta: Rineka Cipta, 2006.

Iriantara, Yosal dan Usep Syarifudin, Komunikasi Pendidikan. Bandung: Simbiosa Rekatama Media, 2018.

Moeleong, Lexy J., Metodologi Penelitian Kualitatif. Bandung: PT Remaja Rosdakarya, 2013.

Nida, Fatma Laili Khoirun, "Komunikasi Bagi Anak berkebutuhan Khusus", Jurnal Komunikasi Penyiaran Islam, Dosen Jurusan Dakwah dan Komunikasi STAIN Kudus, 2013

Rogers, Everett. M., A History of Communication Study: A Biographical Approach. New York : The Free Press, 1994.

Ridwan, Metode dan Teknik Penyusunan Tesis. Bandung: Alfabeta, 2006. Sugiono, Metode Penelitian Kuantitatif, Kualitatif, dan RED, Bandung: Alfabeta, 2008.

Wawancara dengan GK, tanggal 06 Agustus 2019.

Wawancara dengan kepala sekola Khusus Asy-Syifa, 06 Agustus 2019

Wawancara dengan Ibu dina selaku guru kelas IX Sekolah Khusus Asy-Syifa.

Wawancara dengan Guru Kelas (Ibu Dina) di ruangan kelas, 07 Agustus 2019,

Wawancara dengan guru kelas IX(ibu Dina) di ruang kelas, 07 Agustus 2019.

Wawancara dengan Guru kelas (Ibu Dina), 07 Agustus 2019.

Wawancara dengan kepala sekolah (ibu Evi), 08 agustus 2019. 